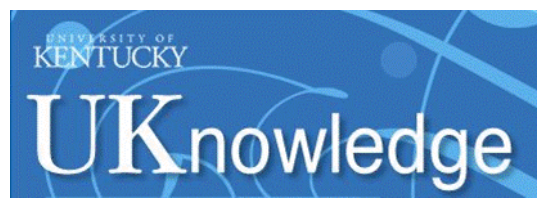

University of Kentucky

UKnowledge

8-1-2013

\title{
Alfred Owre: Revisiting the Thought of a Distinguished, though Controversial, Early Twentieth-Century Dental Educator
}

David A. Nash

University of Kentucky, danash@uky.edu

Follow this and additional works at: https://uknowledge.uky.edu/ohs_facpub

Part of the Dentistry Commons

Right click to open a feedback form in a new tab to let us know how this document benefits you.

\section{Repository Citation}

Nash, David A., "Alfred Owre: Revisiting the Thought of a Distinguished, though Controversial, Early Twentieth-Century Dental Educator" (2013). Oral Health Science Faculty Publications. 1.

https://uknowledge.uky.edu/ohs_facpub/1

This Article is brought to you for free and open access by the Oral Health Science at UKnowledge. It has been accepted for inclusion in Oral Health Science Faculty Publications by an authorized administrator of UKnowledge. For more information, please contact UKnowledge@lsv.uky.edu. 


\section{Alfred Owre: Revisiting the Thought of a Distinguished, though Controversial, Early Twentieth-Century Dental Educator}

\section{Notes/Citation Information}

Published in Journal of Dental Education, v. 77, no. 8, p. 972-981.

Reprinted by permission of Journal of Dental Education, Volume 77, 8 (August 2013). Copyright 2013 by the American Dental Education Association. http://www.jdentaled.org 


\title{
Alfred Owre: Revisiting the Thought of a Distinguished, Though Controversial, Early Twentieth-Century Dental Educator
}

\begin{abstract}
David A. Nash, D.M.D., M.S., Ed.D.
Abstract: Many in dental education are unfamiliar with the professional life and thought of Dr. Alfred Owre, a distinguished though controversial dental educator in the early twentieth century. Owre served as dean of dentistry at both the University of Minnesota, 1905-27, and Columbia University, 1927-33. He was also a member of the Carnegie Foundation's commission that developed the report Dental Education in the United States and Canada, written by Dr. William J. Gies. Owre was a controversial leader due to his creative and original ideas that challenged dental education and the profession. His assessment and critique of the problems of dental education in his era can readily be applied to contemporary dental education and the profession, just as his vision for transformative change resonates with ideas that continue to be advocated by some individuals today. This article also documents his tumultuous relationship with Gies.
\end{abstract}

Dr. Nash is William R. Willard Professor of Dental Education and Professor of Pediatric Dentistry, College of Dentistry, University of Kentucky. Direct correspondence and requests for reprints to him at College of Dentistry, University of Kentucky, 800 Rose Street, Lexington, KY 40536-0297; 859-323-2026 phone; 859-323-4685 fax; danash@email.uky.edu.

Keywords: dental education, dental history, Alfred Owre, William J. Gies

$\mathrm{M}$ any in dental education are unfamiliar with the professional life and thought of Dr. Alfred Owre, a distinguished though controversial dental educator in the early twentieth century. Owre served as dean of dentistry at both the University of Minnesota, 1905-27, and Columbia University, 1927-33. He was also a member of the Carnegie Foundation's commission that developed the report Dental Education in the United States and Canada, written by William J. Gies and published in $1926 .{ }^{1}$

Owre was a controversial leader due to his creative and original ideas that challenged dental education and the profession. His assessment and critique of the problems of dental education then can readily be applied to dental education and the profession today. His vision for change resonates with ideas that have been advanced in the recent past.

Four themes dominated Owre's life and leadership in dental education. He was committed to the following:

- advancing scholarship in dentistry and dental education, emphasizing that education for the profession must be science-based and take place in university-based programs;

- dental education becoming integrated with medical education, and dentistry being understood as a specialty of medicine;
- the utilization of individuals trained for fewer years than dentists performing many of the technical procedures of dentistry (in a group practice); and

- the development of dentists who were "learned and cultured": dentists with not only an understanding and appreciation of science, but also of the role of ethics and the humanities, and dentists who understood their responsibility as leaders in a civic society.

This essay will introduce Alfred Owre, the man and his message, in order to revisit a pivotal and critical era in the history of dental education; demonstrate that some of the issues of dental education have not changed appreciably; and suggest that Owre has not received the credit he deserves in the major reforms of dental education that occurred as a result of the Carnegie Foundation's report Dental Education in the United States and Canada.

\section{A Personal Biosketch}

Alfred Owre was born December 16, 1870, in Hammerfest in northern Norway. (These and other biographical details and all quotations are from Netta W. Wilson's 1937 biography of Owre. ${ }^{2}$ ) His parents 
had arrived in Norway from the United States for a visit with relatives just prior to the birth of their son. They remained in Norway for fourteen years before deciding to re-emigrate to the United States. Though born in Norway, Owre was a U.S. citizen as his parents had become naturalized citizens while in the country previously. As a teenager in Minneapolis, Owre was described by an employer as "a young man of sterling integrity, industrious, good habits, prompt, and attentive to business. We cheerfully recommend him to any firm needing a thoroughly reliable, trustworthy man." A teenage friend said that Owre "was always ready to do more than his share, always more considerate for others than himself. He was a delightful companion." Wilson writes that, as a teenager, unlike his peers who like to "sow wild oats," Owre "preferred his books, his [stamp] collections, and his walks and bicycle rides, partly because of his temperament but also ... because of the strict Quaker teaching in which he had been reared." In his later years he became an agnostic.

Owre's precollegiate education was somewhat irregular. His formal schooling had been in Norway, much of it from extra-school tutoring. When he was interested in applying to study dentistry at the age of nineteen, the matter of his admission was referred to the president of the University of Minnesota, who concluded he could be admitted if he passed the entrance examination. He did and was admitted to the College of Dentistry in October 1891. There, Owre was recognized by the faculty as an exceptional student, possessing a "high degree of manual skill." He graduated in 1895 at age twenty-four. As a good deal of medicine was included in the dental curriculum, in one additional year he was able to complete the requirements for an M.D. degree. A Renaissance man, Owre continued enrolling in university courses even after devoting himself full-time to being a dental educator. Five years after becoming dean of the College of Dentistry at the University of Minnesota, he received his bachelor of arts degree.

Owre was also a world traveler. Among the many countries he visited were Austria, England, France, Japan, China, Russia, Germany, Hungary, and Canada. He was fascinated with cloisonné and is said to have owned over 1,200 pieces, purported to be one of the largest and finest collections in the country. He was a lover of books, with an extensive library, and had an expansive interest in the sciences and humanities. Having developed a taste for tramping as a child in Norway, Owre was a "walker." He walked across the United States, as well as taking extensive walking tours in Europe, Russia, Siberia, China, and Japan. He always carried a walking stick and in his travels purchased a large variety of canes. The extent of his walking is a matter of conjecture, but it was reported in 1924 that he had walked 120,000 miles. Somewhat eccentric in his eating, Owre practiced a strict diet of what today would be considered health foods. He was six feet tall but weighed only 125 pounds his adult life. Owre was married in 1915, at the age of forty-four, to Franc Charlotte Hockenberger, a University of Minnesota graduate and assistant dean of women at the university. The couple had two children.

\section{Early Years as Dean at Minnesota}

After graduating from the College of Dentistry at Minnesota, Owre taught half-time there while engaged in practice in Minneapolis, where he devel-

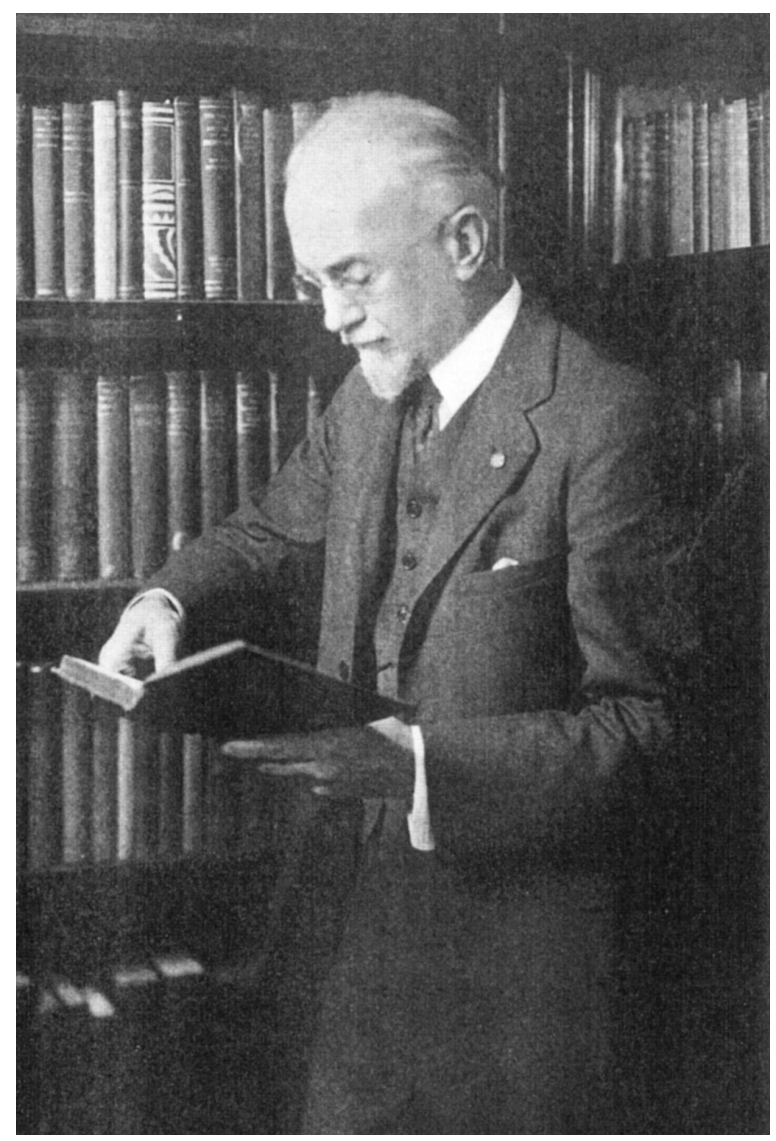

\section{Dr. Alfred Owre}

Source: Reprinted from Wilson NW. Alfred Owre: dentistry's militant educator. Minneapolis: University of Minnesota Press, 1937. 
oped a reputation as an excellent clinician. In 1902, he became a full professor at the university, and in 1905 , at the age of thirty-four, he was named dean of the college.

Abraham Flexner's report Medical Education in the United States and Canada was published in 1910 under the aegis of the Carnegie Foundation. ${ }^{3}$ On reading the report's call for the elimination of inferior, "commercialized," non-university-based schools of medicine and the needed emphasis on science and scholarship in educating physicians, Owre realized the value of such a report for dental education. In 1911, he wrote Henry Pritchett, president of the Carnegie Foundation, asking that a similar survey be conducted of dental education. ${ }^{2}$ In the preface to the 1926 report on dental education, Pritchett acknowledged that it had been known at that time there was a need for a study on dental education but "it did not seem possible to deal with the question of dental education without a larger knowledge than was then available." Whether Owre's letter had any influence on this understanding is unknown.

In the years prior to 1900, the number of dental schools in the United States had increased, in some instances established by prominent dentists primarily for private financial gain rather than for the education of a professional dentist (this practice was true of medical schools as well). The Carnegie survey of 1926 reported there were twenty-eight dental schools chartered in Illinois alone between 1883 and 1902. ${ }^{1}$ However, many of these "commercial" schools were unable to survive more than a few years. This was during the period of time in which Owre became involved in dentistry as a student and member of the faculty at the University of Minnesota - thus his abhorrence of such commercialized dental education.

In a 1915 article in Dental Cosmos, Owre, then serving as dean, lamented the commercial or private control of dental schools, arguing that when commercialism exists, it retards progress since "any advance which will materially interfere with the income of the private institution is quickly voted down." ${ }^{4} \mathrm{~A}$ continual theme of Owre's writings was the imperative for university control of dental education.

He advocated, in that 1915 article, at least one year of university studies for students prior to pursuing the study of dentistry, and argued that the one year should be expanded to two years of predental education as soon as feasible. He stated that such a preliminary requirement was not compatible with commercialism in dental education and would have the potential effect of discouraging it. Additionally, he thought that predental education would help develop the "learned and cultured" dentist he envisioned. He further specified that the study of dentistry should be of four years' duration. Educational preparation to study dentistry and the length of the study itself were important issues of the time and somewhat contentious. Some schools were beginning to consider admission requirements beyond high school, and there was controversy as to whether the dental curriculum should be three of four years in length.

In the mid- to late $1800 \mathrm{~s}$, individuals could study dentistry for a year or two and then begin practice. In the last decade of the nineteenth century, a three-year course of five months each year in the study of dentistry was required; this period was extended to seven months in $1900 .{ }^{1}$ It was not until 1910 that graduation from a four-year high school was required for admission to some dental schools. In 1925-26, high school graduation was a requirement of only sixteen of the forty-four dental schools in the United States. A four-year course of study for dentistry went into effect in schools in $1917 .{ }^{1}$

\section{Carnegie Foundation Survey}

In 1921, Henry S. Pritchett of the Carnegie Foundation appointed William J. Gies, professor and chair of the Department of Biological Chemistry at Columbia University, to chair a commission to conduct a survey of dental education comparable to that the foundation had supported in 1910 for medical education. ${ }^{1}$ In appointing a non-dentist, Pritchett followed in the tradition of the foundation's 1910 report Medical Education in the United States and Canada, led by Abraham Flexner who was not a physician. A probable rationale was to avoid the subjective bias a member of the profession might hold in conducting what was to be an objective survey. Gies was a respected scientist, familiar with topics of dental research. In 1916, he had also been involved in the plans to develop a new dental school at Columbia University. ${ }^{5} \mathrm{He}$ had just led in the establishment of the Journal of Dental Research. ${ }^{6}$

When the Carnegie commission was being constituted to study dental education, Owre was the president of the Dental Faculties Association of American Universities, which he had been a prime mover in establishing in 1908. This association promoted scientific dental education, in opposition to proprietary schools. Gies requested Owre's assis- 
tance in identifying dentists who might serve on the commission. Owre was eventually named a member, along with four other dentists, three physicians, and three educators. Owre was effusive about the work of the Carnegie survey stating, "The Carnegie survey is going to be the greatest aid to the progress of dental education that we have ever had. I am positive Dr. Gies is the man for the job and that we now have the sympathy and cooperation of a very large majority of the dental forces. What the Carnegie survey did for medicine, the current study will undoubtedly do for dentistry ... as you know medical standards were raised immeasurably." ${ }^{2}$

\section{Predental Study and Commercial Dental Schools}

In 1921, at the outset of the Carnegie study, Owre wrote Gies regarding the structure of the dental curriculum. He wrote that "ten or twelve years ago we [the Dental Faculties Association] began to fight for a predental year, with three years of dentistry; we had to compromise instead on four years of dentistry [without a predental year]. Certain members of the association feared to face opposition from the commercial schools to a predental year. The four-year arrangement permitted these schools to collect an additional year's fee for what should have been academic work. . . . When it came to the question of a five-year course, involving the predental year, we had doubled our membership and the stronger schools were in the ascendancy ... helping make the predental year possible."

It was not until 1924 that at least one year of predental academic study was made an entrance requirement. At that time, only twenty-two of the forty-three dental schools required academic study in a college prior to admission. ${ }^{1}$ The Carnegie Foundation's report, released in 1926, recommended that the predental curriculum consist of two academic years of study, stating that "the preparatory education of dentists should be equivalent, in general character, to that of physicians," which then was of two years' duration. ${ }^{1}$ Three years of study in dentistry were to follow, for a total of five years of postsecondary education - a strategy that Owre had been advocating for the previous sixteen years and largely for the same reason.

Owre's focus for these many years on the importance of predental study was not only to battle the influence of commercial or proprietary dental schools, but to ensure that the academic qualifications for dentistry were comparable to those of medicine. His focus on an academic preparation to study dentistry also related to his view of the dentist as a "cultured" professional, an issue that will be addressed below.

\section{Integrating Dentistry with Medicine}

Owre had for some time held the view that the separation of dentistry from medicine was "baneful" and that, in the last analysis, dentistry was but a specialty of medicine. ${ }^{7}$ In an address at Columbia University in 1922, Owre emphasized that the fundamental conception of a dentist was that of a physician. He called the cleavage of dental education from medical education in Baltimore in 1839 a "crime." ${ }^{8}$ One year later, at the presidential address to the Dental Faculties Association at the University of Iowa, he stated, "our original status was that of a specialty in medicine." He continued, "The best scientific thought is agreed that dentistry is a field of medicine. ... There is no logical right whatever to isolate [the oral cavity] from the rest of the body as if it were made up ... of ivory pegs in stone sockets. Modern research has established conclusively that the mouth is the center of numerous infections. We can never go back to the old 'jeweler' days."

In addressing the Minnesota State Dental Association in 1923, he said, "If dentistry makes good its claim as a profession, its former independence [from medicine] must disappear . . . and in time there can be worked out a joint curriculum [for dentistry and medicine] without lengthening the course beyond their present limits of the medical course, possibly even shortening that - which will entitle a dentist to rank as an oral specialist in the greater field of medicine."10

As the Carnegie survey process was just beginning, Owre wrote Gies on October 24, 1921, expressing his assumptions regarding the direction dental education should take in the future:

"Dental" education-badly misnamed-
should branch off somewhere from the tree
trunk of medical education, a tree which
has for its roots preliminary training in
mathematics, physics, biology, chemistry,
and foreign language, and English compo-
sition. It should have the same relations to 
the parent stem as does the study of other regions, e.g., brain and nervous system, eye and ear, nose and throat, chest and heart, etc. The specialist in the oral region should have the same standing as the specialist in any other region. His work is as essentially vital, involving vital tissues, and requiring thorough biological knowledge from it for its proper practice. This is the fundamental necessity-to train specialists in the mouth region, capable of diagnosing and prescribing for ills of the mouth. It [would be] as logical, as you have pointed out, to require an eye specialist to make all eyeglasses for which he writes prescriptions as to expect the oral specialist to fill, clean, or otherwise mechanically treat all teeth his diagnosis finds faulty. It is possible to train men for the mechanical work in a much shorter time than is required for the oral specialty, and in much greater numbers. ${ }^{2}$

Gies's views were fundamentally aligned with Owre's. Columbia University had established a dental school in 1916, and the founding document, A Dental School on University Lines, stated that "dentistry has been shown by recent investigations and research to be logically a branch of general medicine."5 Gies was one of four members of the Medical Faculty who participated with sixteen members of a Dental Committee in writing the document. ${ }^{5}$ In an address early in the survey process, Gies expressed the view that "the practice of medicine and the practice of dentistry are coordinate divisions of health service. Dentistry belongs on a plain of full equality in all respect with every other agency in scientific health service for individuals and communities in particular, and for humanity in general." It is not unreasonable to assume that Gies's earlier thinking regarding dentistry was further shaped and influenced by Owre. In his book on the life and influence of Gies, Orland states: "Because he was not really a dental educator Gies relied heavily on others in the dental field, especially Alfred Owre, dean of the dental school at the University of Minnesota." "Gies went on to state in the final Carnegie Foundation survey:

Recent advances of science ... have shown that certain common and similar disorders of the teeth may involve prompt or insidious development of serious or possibly fatal ailments in other parts of the body. ... The import for both dentistry and medicine of these significant findings is obvious. They force the conclusion that dentistry is an important mode of health service and that in general it is quite as significant for maintenance of health as some of the accredited specialties of medical practice. Dentistry should no longer be ignored in medical schools and its main health service feature should be given attention to the training of general practitioners of medicine. ... The practice of dentistry should be made either an accredited specialty of the practice of conventional medicine or fully equal to such a specialty in the grade of health service. ${ }^{1}$

As a member of the Carnegie Foundation commission, Owre advocated for the integration of the education of dentists with that of other physicians and for dentistry to become a specialty within the larger field of medicine. The commission ultimately did not follow his lead, determining that significant barriers existed for that to happen including medicine's general resistance, the growing demand for dental practitioners that could not be met by medical schools without significant expansion, the rigidity of the medical curriculum, the unyielding views of medical state boards and medical educators, and the resistance of dentists themselves. Ultimately, the report, Dental Education in the United States and Canada, concluded that since dentistry at that time could not be made a specialty within medicine, it must be understood as an "equivalent of an oral health specialty of the practice of medicine."

\section{Dentists Delegating Technical Duties}

Owre conceptualized a dental team caring for the oral health needs of the public. In a letter to Gies in 1921, he wrote, "It is possible to train for the mechanical work [of dentistry] in a much shorter time than is required for the oral specialist [dentist], and in much greater numbers. The former should work only under direction of the latter." He went on to say that "dental education in the United States is in a hopelessly chaotic state. It is folly to put all types through the same mill. The mechanical type should be recognized as such and trained for mechanical work - two years or less will do it."2 Speaking before the Association of Urban Universities in Buffalo in 1927, Owre asserted that dentists would eventually 
have to become members of the medical profession specializing in the oral cavity and that they would need to be assisted by technicians who would provide the bulk of the routine dental care. ${ }^{13}$

In 1923, the Carnegie survey initiated a census of dentists in the country; Owre compiled the figures for Minnesota. The commission had considered that young dentists tended to concentrate in urban areas rather than small towns. Owre's survey of Minnesota confirmed this. His solution was the training of dentists as specialist physicians, with others trained to do the mechanical/technical work under the guidance of the dentist/physician, suggesting that "such a readjustment might in the end benefit the smaller communities ... which report insufficient service."

In 1924, Gies had written Owre asking about the ability of a technician working under the supervision of a dentist to provide more care than the dentist would normally be able to provide. Owre replied, "I believe a dentist with adequate help from dental technicians could give more than twice as much personal service to patients than he could ordinarily render without such help. This would involve, however, not one helper but several 'mechanicians' trained in various phases of dental technic."”

Ultimately, the Carnegie report did not support Owre's perspective on the use of allied professionals in dentistry. The report stated that "the practice of health service as applied to the teeth and the adjacent tissues cannot be divided between stomatologists as prescribers, on the one hand, and dental technicians as mechanical experts on the other ... for the reason that the actual practice of dentistry must be in the mouth itself and requires a union of medical knowledge, tactual skill, and mechanical precision not called for in other specialties of medicine."1

The newly formed American Association of Dental Schools, holding its annual meeting in Memphis in 1931, passed resolutions declaring "the interests of public health, and of the medical and dental professions, would best be served by a continuation of the separate organization of the dental profession" and that "the recently advocated concept of an ideal dental service to be practiced by a physician-dentist, assisted by a group of technicians, is neither practical nor logical, nor conducive to the best interests of the public." ${ }^{2}$ This view of the practice of dentistry subsequently led to furious opposition to Owre and his advocacy for reform. Dentists were profoundly shocked by the notion that a person without full and complete training in dentistry should be allowed to have anything to do with the mouths of patients.

\section{Relationship Fractured}

In January 1927, one year after the release of the Gies report, Alfred Owre was appointed dean of the School of Dental and Oral Surgery at Columbia University. Among the several policies he planned to follow at Columbia was to emphasize that "dentistry should be a specialty in medicine; and we aim to realize this with the cooperation of the medical faculty as soon as educational adjustments can be satisfactorily made."

In 1929, the American College of Dentists, meeting in annual session in Chicago, considered the following question: "shall dentistry continue separately organized, or become a part of statutory medical practice?" A five-person commission of the college, of which Gies was a member, had been studying the question and presented a report to the college that included the following: "that dental practice could more effectually fulfill its functions by becoming an integral part of medical practice does not represent the views of more than an extremely small minority of the members of the dental profession." The associated resolutions were sent by mail ballot to members of the college; the final vote was 254 to 13 in favor of the resolutions opposing integration with medicine. ${ }^{2}$

Gies and Owre were on opposite sides of this issue. Since the Carnegie report on dental education, published three years previously, these men (both of whom had been intimately involved in the survey) had clashed on the conclusions ultimately reached. The report stated that "the practice of dentistry should be made either an accredited specialty of the practice of conventional medicine, or fully equal to such a specialty in grade of health service." Gies was committed to the view that, due to the barriers identified in the report, dentistry could not at that time become a specialty within medicine. Owre, on the other hand, continued to be committed to his vision of the integration of dental education with medical education and dentistry becoming a specialty within medicine. ${ }^{14-17}$

The relationship between Gies and Owre became personally adversarial when Owre published and distributed through Columbia a paper he had presented at the First Congrès International de L'Association Stomatologique International in Budapest in $1931 .^{18}$ (The article with appendix was ninety-three pages.) With Owre's recognized zealousness for change, the paper began: 
For many years there has been a widespread belief throughout Europe that American dentistry and dental education have been concerned almost exclusively with perfecting mechanical restorations - that no attention has been given to the scientific aspect of work in the oral cavity, nor to the relationship of dentistry to medicine and surgery. There is, unfortunately, a certain basis for this belief. Generally speaking, the "profession" of dentistry in America has lacked the education foundation without which no group has a right to call itself a profession. Emphasis has been on technique, with no recognition of oral work to the general health. ${ }^{18}$

He proceeded to provide his perspective on the conflicts among the various organizations involved in dental education at the time and their involvement in the Carnegie survey. In doing so, he was highly critical of the Dental Education Council (DEC), which, with the formation of the American Association of Dental Schools (AADS) in 1923, had eighteen delegates: six each from the AADS, the American Dental Association, and the National Association of Dental Examiners. Owre had been president of the Dental Faculties Association of American Universities, which consisted of progressive university-based dental schools promoting quality improvements in dental education. That association reluctantly merged with other groups to form the AADS - the reluctance was because its members believed the newly formed group would not be as stringent in demanding quality improvement in dental education as their association had been. Gies had advocated for these groups joining to form the AADS. Even though he was a delegate to the DEC from the AADS, in the Budapest address Owre stated that the DEC was actually on the side of lower rather than higher standards in professional education, due to the influence of proprietary interests on that organization. He further intimated that the Gies report had been strongly influenced by the DEC and, as a consequence, had not been as strong and effective in its recommendations as many had anticipated.

Gies could not let these statements stand and rebutted them in the Journal of Dental Research, calling Owre's comments "prejudiced," "unfair," "unjust," with a "wanton disregard for truth," "intentionally offensive," and a "gross misrepresentation." 19 The congeniality and collegiality reflected in their early work on the Carnegie survey were forever ruptured. Of interest is that Owre was the dean and Gies was a member of the faculty at Columbia during this period of professional and personal tension.

Owre continued to affirm that his "scheme" was that dentists should be educated in the medical schools and receive the same basic education as individuals in the various other specialties of medicine. These scientifically educated specialists in oral health should then lead a team of individuals trained to provide much of the specific technical aspects of care. In an article in the Journal of the American Association of Medical Colleges in 1931, he wrote: "In a well-organized practice the major portion of restorative work should be performed by well-trained assistants. . . . Intraoral work should be permitted by several types of specifically trained assistants, under the responsible supervision of the specialist [dentist]." He continued: "It is poor economy to insist that only the specialist's hands may work in the oral cavity. To the extent that the master-type can employ a variety of helpers, to that extent can he increase his usefulness." He went on to acknowledge that dental hygienists were at that time being trained in some universities and stated his belief that "their training could well include much of children's dentistry, and without exceeding a calendar year." 20

In 1932, a Final Report of the Committee on the Costs of Medical Care was made public. ${ }^{21}$ Among the references to dentistry was the following: "We commend the growing tendency in the practice of dentistry toward a division of labor in which a dentist who is also a physician assumes larger responsibilities for the diagnosis and treatment of conditions arising from or related to the teeth, while much of the routine performed by the dentist in the past is delegated to dental hygienists and other technicians working under his direction." The statement was a footnote in the report signed by Owre and six others who had been members of the larger committee evaluating the cost of health care generally. On learning of the report and the footnote on dentistry, Gies objected strongly in an article in the Journal of Dental Research. He accused these seven committee members of "misrepresenting the conditions in the practice of dentistry [in the United States and Canada]." ${ }^{22}$ Owre responded by saying that Gies had "viciously attacked" the footnote and should have known that the footnote in the report had been made in the context of dental practice in the world. Owre went on to assert that, in considering the cost of medical care, good dentistry was expensive and required 
better organization to reduce its cost. He stated that "group practice in dentistry is especially feasible because for the most part dentistry is routine. . . It can be fitted easily into a group scheme and share in the reduced overhead and increased efficiency of such practice." 23

The dean of the medical school at Columbia had previously acknowledged support of Owre's views on the value of educating medically trained oral health specialists supported by technicians trained in fewer years. Noting "these ideas would mean a rather radical reorganization of dental education and dental practice," he stated that "such a plan should reduce the cost of dental care to a very considerable degree." ${ }^{2}$

\section{Need for "Learned, Cultured" Dentists}

Alfred Owre's vision throughout his career was to educate individuals not only as scientifically oriented dentists but also as "learned, cultivated gentlemen." Owre expanded the library at the Minnesota dental school with books on history, psychology, philosophy, education, literature, sociology, ethics, art, and architecture, as he did not want it to be limited to works on dentistry. He provided students with a list of books he recommended for their reading. On leaving Minnesota for the deanship at Columbia in 1927, the university librarian said to him, "I hope you will never . . . forget what you have been doing all these years to get dentists to read something besides dentistry." 2

Owre believed that exposing students to great literature would open new vistas to their understanding. He lamented that few dentists were readers and as a consequence were not the thinkers they could be, attributing much of this to the then inadequate predental collegiate education. In a 1915 article in Dental Cosmos, he advanced an argument for the importance of dentists being engaged in society and concerned about the well-being of all, not merely with the materialistic perspective of "what can I get out of it." He wrote that "there is nothing so sad in this world as a limited outlook. . . . To realize one's self, to externalize the depths of one's soul or inner self, is the great aim of life." He argued that dental education must "produce men capable of entering into the larger life of the community, men who can function maximally as citizens.... The future dentist must be able to live in the real interest of the day; he should have broad views of the whole range of questions that are vital to the hour. The isolation of any man from these things makes him a machine, an automaton, and an irresponsible being." ${ }^{4}$ His views never changed. In a 1931 article he wrote, "To be a truly professional man, the dentist should be a cultivated person, with the scientific attitude and method, and with an appreciation of knowledge for its own sake ... men with genuine university training and outlook." ${ }^{24}$

The Carnegie report advanced these ideals, stating that the dentist should be "an educated man, with a background of culture and refinement." It went on to say that "a liberal education and ... the perspective of cultural study guard the mind and the spirit against the relatively narrowing influences of a professional training."

\section{Controversy at Columbia}

Owre must have realized the challenges he would face at Columbia. Five years earlier he had been warned by his friend and then dental dean at Columbia Dr. Van Woert. Although Van Woert was supportive of Owre's vision for dental education, he cautioned Owre about an "undercurrent of rebellion on the part of some of our politicians ... and a battle that will have to be fought."' Owre was undaunted as he eagerly anticipated the opportunity Columbia offered him to lead the kind of school he had dreamed of establishing.

Coincident with his arrival at Columbia and the construction of a new Medical Center, a decision was made to establish "a dental service at a moderate charge to persons in moderate circumstance who are unwilling to accept charity treatment and are unable to pay the present scale of fees of the dental profession." Whether the concept was introduced by the Columbia administration or by Owre is unknown, but Owre was supportive of the approach. The reaction of the practicing community was not positive. This, along with his idea of integrating dentistry with medicine in education and practice and his known views of delegating much of the technical work of dentistry to allied professionals, resulted in him being viewed by many as a fanatic.

In her biography, Wilson writes that "Owre, his eyes fixed on his great objective, [was like] many another leader of a high cause," in that "he believed all who were not definitely with him were against him. 
It was his uncompromising attitude, his inability to see virtue even in honest opposition, that eventually brought about the defection of many who would have been glad to give in part way if he had been willing to do the same."

In 1933, a commission of the Columbia dental school faculty forwarded charges against Owre and his leadership of the school to the president and asked that Owre's deanship be terminated. Included in their charges was that Owre had made himself thoroughly unpopular with the dental profession, which he had antagonized beyond hope of reconciliation. Owre was granted a sabbatical from Columbia for 1933-34. He had hoped to return to his duties subsequently, when the turmoil was somewhat abated. This was not to be since, shortly after returning from an extended period studying dental education in Europe, Owre was stricken with a mysterious illness and died in 1935 at the age of 64 .

\section{Owre and the Reformation of Dental Education}

It is of historical interest to note the role that Alfred Owre had in the reforms that occurred in dental education associated with what is now known as the Gies report. He was an early advocate for such a survey of dental education. Owre was a leader in the formation of the Dental Faculties Association of American Universities, formed in 1908 to counteract the influence of the commercial, non-universitybased dental schools. While serving as president of the organization in the early 1920 s, he was asked by Gies to identify dentists to serve on the survey commission, which he did. Owre served on the commission and was influential in providing leadership of the conduct of the survey including making visits to many of the dental schools himself.

Of greatest interest, however, is that the report Dental Education in the United States and Canada in its recommendations and conclusions proved substantively to be both an affirmation and a repudiation of the intellectual thought of Owre, all of which had been advanced by him in his scholarly writing prior to the report. The report:

- substantiated Owre's view of the imperative of two years of predental education, comparable to medicine;

- emphasized that dental education was sciencebased and must be taught in recognized universities;
- stated that commercial or proprietary schools had no place in dental education;

- while acknowledging that dental education was a specialty health service equivalent to other specialties of medicine, rejected Owre's belief that dentistry should be integrated with medicine as a specialty and that dental education should be integrated with medical education; and

- rejected Owre's view that dentists should lead a cadre of trained dental technicians who would accomplish many of the technical tasks of the dentist and could help address the issue of access to care in smaller communities.

Owre's intellectual leadership of dental education in the early years of the twentieth century is reflected throughout the report. The report dealt with the problems of dental education about which he expressed his vision and convictions extensively in his writing and speaking.

Owre's concerns regarding dental education and the profession of dentistry continue to exist today. His thought foreshadows calls today by a number of dental educators for greater degrees of education and training in medicine, with dentists becoming physicians of the oral cavity; for emphasizing the relationship of oral health to general health and wellbeing; for the introduction of dental therapists to the oral health workforce; for increased development of group practices; for greater scholarship in dental schools; for developing dentists who are liberally educated in the arts and sciences; and for issuing calls of concern regarding the establishment of dental schools not associated with traditional universities. His creative, though controversial, vision for transformative change resonates in today's environment and continues to require thoughtful consideration by leaders in dentistry and dental education.

\section{Acknowledgments}

The author acknowledges Dr. Jay W. Friedman, who introduced him to the life and work of Alfred Owre with the gift of Netta Wilson's biography. Actually, this was a second generation gift as the book was given to Dr. Friedman when he was a dental student at Columbia by his dentist father, Dr. Carl I. Friedman. Additionally, the author acknowledges with gratitude the constructive review of this essay by Dr. Allan Formicola, Dean Emeritus at Columbia and an individual well versed on the subjects of both William Gies and Alfred Owre as well as the history of dental education. 


\section{REFERENCES}

1. Gies WJ. Dental education in the United States and Canada. Bulletin number 19. New York: Carnegie Foundation for the Advancement of Teaching, 1926.

2. Wilson NW. Alfred Owre: dentistry's militant educator. Minneapolis: University of Minnesota Press, 1937.

3. Flexner A. Medical education in the United States and Canada. Bulletin number 4. New York: Carnegie Foundation for the Advancement of Teaching, 1910.

4. Owre A. Dental education. Dent Cosmos 1915;57:166-73.

5. Columbia University. A dental school on university lines. New York: Columbia University, 1916.

6. Orland FJ. William John Gies: his contribution to the advancement of dentistry. New York: William J. Gies Foundation for the Advancement of Dentistry, 1992.

7. Owre A. The teaching of the ancillary and so-called "medical" subjects in the four-year dental course. Proceedings of the American Institute of Dental Teachers, Philadelphia, January 23, 1917. In: Wilson NW. Alfred Owre: dentistry's militant educator. Minneapolis: University of Minnesota Press, 1937.

8. Owre A. Dental education. J Dent Res 1922;4:cxvii-cxxvii.

9. Owre A. President's address to the Dental Faculties Association, University of Iowa, January 1923. Proceedings of the Dental Faculties Association, 1908-23, 109-11. In: Wilson NW. Alfred Owre: dentistry's militant educator. Minneapolis: University of Minnesota Press, 1937.

10. Owre A. Goal of dental education. J Am Dent Assoc 1923;10:328-41.

11. Owre A. A view of dental education. Minneapolis District Dent J, Sept. 1922. In: Wilson NW. Alfred Owre: dentistry's militant educator. Minneapolis: University of Minnesota Press, 1937.

12. Owre A. Comments on the Carnegie survey of dental education. J Am Dent Assoc 1927;14:1222-36.
13. Owre A. The predental course: an address delivered before the Association of Urban Universities, Buffalo, 1927. In: Wilson NW. Alfred Owre: dentistry's militant educator. Minneapolis: University of Minnesota Press, 1937.

14. Owre A. Medical education for the dentist. Rev Clin Stomatol 1925;2:40-2.

15. Owre A. Dentistry in medicine. Dent Survey 1930;26-8.

16. Owre A. Is dentistry at a crossroads? Dent Cosmos 1930; 72:1061-72.

17. Owre A. Relationship of the physician and the dentist. Dent Survey 1931;7:21-4,80-2.

18. Owre A. Some phases of dental education in the United States. Proceedings of the First International Congress of the International Association of Stomatology, Budapest, September 2-7, 1931.

19. Gies WJ. Comment on some misstatements regarding the Carnegie Foundation's study of dental education. J Dent Res 1932;12:865.

20. Owre A. Dental education as related to medical education. J Am Assoc Med Coll 1931;293-303.

21. The final report of the committee on the cost of medical care. Chicago: University of Chicago Press, 1932.

22. Gies WJ. The final report of the committee on the costs of medical care: comment on a misrepresentation of conditions in the practice of dentistry. J Dent Res 1933;13: 81-98.

23. Owre A. An analysis and digest of the report of the committee on the costs of medical care in its effects upon the profession and the public: an address before the Kings County Dental Society, Brooklyn, February 1933. In: Wilson NW. Alfred Owre: dentistry's militant educator. Minneapolis: University of Minnesota Press, 1937.

24. Owre A. Possible educational solutions of the socioeconomic problems of the professions of medicine and dentistry. J Dent Res 1931;11:653-9. 